\title{
SETTLEMENT AND UNSETTLEMENT IN THE RESETTLEMENT ADMINISTATION PROGRAM
}

\author{
Clarence A. Wiley*
}

In the by and large, the Resettlement Administration had no particular program which can be said to have arisen strictly out of the administrative set-up which functioned during the period from July I, 1935, down to December 31, 1936. On the one hand, the program which it administered was an adopted child whose paternal forbear was the F.E.R.A., which later employed tutors and guardians in the form of state Rural. Rehabilitation Corporations. ${ }^{1}$ The particular phase of the Resettlement Administration's program known as rehabilitation related especially to that portion of its work which was designed primarily to advance subsistence and capital goods to very low-income farmers who, without such assistance, could not continue to carry on their farming operations. This inability to carry on resulted, from region to region or within a given region, from a multiplicity of causes such as, crop failure, foreclosure on land or livestock, loss of supplementary employment, or the occupancy of poor land giving forth only meager yields that had to be sold at depression prices. The other aspect of its program was inherited from the National Resources Committee and attempted to deal primarily with those aspects of the farm problem which grew out of a misdirected, not to say vicious, national land policy.

The program, therefore, cannot be said to be that of any particular national or state governmental agency. It rather represented the consolidated programs of various national and state agencies, some portions of which were designed to be stop-gaps, plaster, and patch-work upon the tattered and smeared agricultural pattern then existing. For the most part they consisted of emergency measures for an emergency situation. Other phases of the program attempted to apply remedies to chronic maladjustments that had been destined sooner or later to bring the distress to agriculture which was in fact ushered in sooner by the depression.

* A.B., I920, A.M., 1921, University of Texas; Ph.D., 1926, University of Wisconsin. Professor of Economics, University of Texas. Author: Agriculture and the Business Cycle since 1920-A Study in the Disparity of Prices. Contributor to professional economic journals. The writer was for a brief period in 1935 Acting State Director, Rural Rehabilitation for Texas. For some time thereafter, until September, 1936, he was Chief, Land Use Planning Section, Resettlement Administration, for Region V which com: prises the states of Alabama, Georgia, South Carolina, and Florida-an area manifesting almost every aspect of land problems possible anywhere.

${ }^{1}$ The legislative and administrative development of the program is discussed in Oppenheimer, The Development of the Rural Rehabilitation Loan Program, infra p. 473. ED. 
In broad perspective, therefore, the program consisted of two main segments: (I) temporary relief, either as outright grants, or in the form of loans at low rates of interest for subsistence and for capital goods; (2) long-range planning that involved readjustments in land use, more economical sized farms, better systems of farming, feasible cooperative arrangements among farmers, soil conservation, retirement from use of submarginal crop lands, and opportunity for the resettling on good farm lands of farm families stranded on poor land. The entire program was a rather ambitious one, and one which had need for the best administrative and technical advice available in the nation. However, the magnitude of the task, its emergency character, the decentralization of planning (especially in the long-range aspects of the program), the absence of provision for scissor wielders on administrative red tape, the delay in reaching decisions, and frequent changes in policy all contributed to about as much unsettlement as settlement and resettlement in the program. A more complete analysis of the program, with a sympathetic effort to appraise the various methods of approach to the multiplicity of problems presented, will be attempted following a brief survey of the agricultural situation which seemed to justify the gigantic nation-wide attempt at temporary remedial measures and long-range adjustments.

\section{Acute Agricultural, Apoplexy}

The health of the agricultural industry has been none too good since its spree of expansion, technological improvement, and land speculation instigated in part by its own initiative and in part as the result of governmental policy during and immediately following the World War. Beginning in the fall of 1920 it began to experience the severe morning-after headache that follows the night before. The conjunction of events thereafter was not such as to permit complete recovery, with the result that the depression struck a weak and tottering industry such a blow that remedial measures were inevitable. The final "stroke," however, was only a symptom of many organic ailments of long standing. This situation was not peculiar to agriculture. Financial institutions, manufacturing establishments, transportation companies, etc., also had taken their sprees and experienced their headaches. Resulting ailments and maladjustments were partly of an emergency character, and in part also of a chronic nature. The cries for governmental succor rose up from every nook and cranny of our economic system. The particular assistance given agriculture, indeed, was different from that administered to non-agricultural enterprises, but only in the extent and degree to which seasoned judgment considered warranted by the exigencies of the situation and the peculiar nature of the industry and its current problems.

The agricultural situation which confronted the nation once the depression had wrought some of its havoc upon the agricultural population may be glimpsed by the following brief summary. Rather early in the depression the nation found itself confronted with the problem of providing food and shelter for a vast army of unem- 
ployed of undetermined size. Unemployment was a fact, and the situation demanded action. It was no time to weigh judgments as to the degree of individual responsibility for one's situation. Unemployed farm laborers, dispossessed tenants, farmers who were out of work because they had lost either their teams and tools or their land, and farmers who had some land but insufficient moisture, or were lacking seed to carry on their farming operations, presented largely the same problem as did the unemployed from non-agricultural industries. Others still on the land had made so little and/or got so little for what they made that they were without subsistence for themselves and their work animals until another crop could be harvested. Little work and less credit were available under the existing situation. Therefore, when the F.E.R.A. was established in May, r933, many rural cases were cared for under the program, especially during the following winter months. Under the above program cash grants were made to the several states for direct or work relief under federal supervision. In the fall of 1933 the C. W. A. was set up to provide jobs for those unemployed and for those whose incomes from employment were deemed inadequate to provide reasonable subsistence. In the spring of 1934 this feature of the program was displaced by the work relief program of the F.E.R.A. The intention was to give jobs to relief clients in order to dispense with direct relief because of the disfavor with which the "dole" was generally regarded. But work relief was less available to unemployed farm laborers and heads of other distressed farm families than to the unemployed in other fields, unless they migrated to the villages and towns, a thing which many of them did.

In the process of aiding needy farm families, it soon occurred to F.E.R.A. offcials that these families logically fell into two main categories. First, there were those who needed only subsistence for themselves or their livestock, and funds for medical care, clothing and planting seed. When work relief was given, wages were usually credited against advances made. Practically all distressed farmers in the western drought area were cared for in this manner, up to the spring of 1935, on their purchases of feed. Along with work relief there was also a greater or less volume of direct relief grants, varying of course from one family or locality to another. Second, it was evident that there were many farmers (and farm laborers to a lesser degree) who could become self-supporting if given advances in cash in the form of loans with which to buy teams, tools and equipment, seed, and fertilizer in addition to grants for subsistence. Loans and grants of this sort were designated "rehabilitation" on the assumption that this policy would eliminate recurring direct relief grants. Consequently, in the spring of 1934 by administrative order a separate Rural Rehabilitation Division was charged with the responsibility of handling the needs of distressed farm families in the western drought area.

At the expense of the omission of a vast amount of detail incident to the administration of the program, the chief point of interest here is to indicate the magnitude of the task involved, and the national scope of the program. By the winter of 
1934-35 something over one million farm and farm laborer families ${ }^{2}$ were receiving relief grants and/or rehabilitation loans, a fact which is indicative of the extent of rural distress. Indeed, approximately two million families received relief at one time or another during the depression. A significant fact about this tremendous number of distressed farm and farm laborer families is that the bulk of them was concentrated in fourteen states representing only one-fourth the farms of the United States. This peculiar situation points very definitely to the conclusion that there is a distinct causal connection between the ratio of distressed families to total farm families in an area, and the particular rural economic and social patterns of that area. The fourteen states in order of their ratio of farm operators receiving relief to all farm operators in the state are as follows:

Ratio on relief

New Mexico ............................ 36

South Dakota .............. 33

North Dakota ............. 27

Oklahoma .............. 27

Colorado ................ 22

Kentucky $\ldots \ldots \ldots \ldots \ldots \ldots \ldots$ r. 19

Florida ................. r8
Ratio on relief

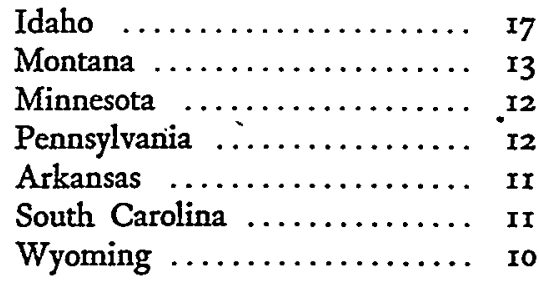

These fourteen states may be definitely classified according to the predominant feature, or features, responsible for agricultural distress. In the main, they are external to the economy of the individual farmer, and therefore, largely beyond his control. Chief among these by states were:

\begin{tabular}{lll} 
Drought & \multicolumn{1}{c}{$\begin{array}{c}\text { Abandonment or } \\
\text { removal of industry }\end{array}$} & \multicolumn{1}{c}{$\begin{array}{c}\text { Phical features: } \\
\text { poor land, rugged, eroded. } \\
\text { Overpopulated }\end{array}$} \\
New Mexico & Pennsylvania* & South Carolina \\
Oklahoma & Kentucky* & Arkansas \\
Colorado & Florida* & Kentucky* \\
Idaho & Minnesota* & Pennsylvania* \\
Montana & & Florida* \\
Wyoming & & \\
North Dakota & \\
South Dakota & \\
Minnesota* & & \\
- States affected by more than one factor.
\end{tabular}

The above classification of causes for distress in agricultural areas is perhaps in categories too broad to reveal significant implications with reference to individual farm problems. For this reason, it should be broken down, and numerous other contributing factors added. Moreover, additional light can be thrown on the nature of the problems, in so far as they were either directly or indirectly causes of recent

\footnotetext{
${ }^{2}$ It is important to note, however, that all these families were not currently engaged in agriculture. Many of them had left the farm earlier in the depression to seek employment in villages and towns. On account of their usual occupation they were classified as farm families.
} 
farm distress, by classifying them as (I) more or less temporary contributing factors and (2) long-run factors contributing to maladjustments in land use and to low farm family net incomes. Some attempt, therefore, has been made in the table below to arrive at such a classification, however inadequate it may be.

(I) Drought

(2) Floods

(3) Loss of job

(4) Foreclosure on livestock and/or farm

(5) Dispossessed as tenant

(6) Loss of assets through depression prices or otherwise

(7) Death or ill health of earning member of household

(8) Unavailable credit resources

(9) Low purchasing power of farm products incident to the depression
Chronic, or long-range factors contributing to current maladjustments

(I) The pressure of rural birth rate in relation to rural economic opportunities

(2) The use of sub-marginal lands for cropping purposes

(3) Soil depletion resulting from uneconomical farming practices

(4) Farm units too small

(5) Failure to adopt farming systems adapted to character of an area

(6) The depletion of natural resources, frequently timber, which normally provided supplementary employment

(7) Over-capitalization of land values

(8) The swelling intensity of institutional forces conducive to inequality of rural opportunity, resulting in poverty, tenancy, and large numbers of unattached laborers.

It was the incidence of this multiplicity of emergency and long-run factors which fell with crushing weight upon approximately one-third of the farm families of the nation at one time or another during the depression. So far as the rural problem was concerned, it was with this large and widely scattered group of afflicted rural families that the F.E.R.A. and the Rural Rehabilitation Corporations attempted to deal. A cross section of this group in June, 1935 , reveals 138,000 farm owners, 280,000 tenants (other than share croppers), 44,000 share croppers, and 147,000 farm laborers. From this cross section of those in need of aid, it is evident that great variation existed as to (I) the causes of their distress and (2) the type of aid which would be most effective.

For all those who still had land and livestock to carry on current operations, or begin another year's crop, but whose liquid assets had been exhausted, and whose current incomes had been depleted or reduced to nothing, the need was primarily for an immediate source of income. This could be provided in the main only from work relief or direct relief grants. Whenever work could be provided by F.E.R.A., or C.W.A., wages were paid in cash or credited against relief grants, provided they were loan cases. Still another group comprised low-level owners, some tenants, many share croppers, and perhaps a still larger proportion of farm laborers who were partially or wholly deficient in either land, livestock, or tools and equipment. These 
needed aid of a little different character, else relief grants would be ever-recurring events. Farmers who had an even chance or better to attain a self-supporting status, provided they could receive advances temporarily in the form of subsistence and capital goods, were eventually transferred from the general relief rolls to the custody of the Rural Rehabilitation Corporations. Farm operators carrying on in this capacity were thereafterwards referred to as rehabilitation clients. ${ }^{3}$

On this basis of selection, it is evident that a large majority of such clientele would be located in the southern states where poverty and illiteracy held their strongest grip. More farm operators, both white and black, who were deficient either in land, or teams and tools, or all of these at once, could be found in the South than in any equal area in the country. Accordingly, in February, 1935, more than ninety per cent of rehabilitation clients were located in ten southern states. For the most part, then, the rural rehabilitation program in the South was a device for "furnishing" croppers and tenants, although smaller percentages of farm owners and farm laborers were included in the program. However, during the spring of 1935 the number of rehabilitation cases increased very markedly in the Southwest and the far Middlewest because of an administrative ruling which required the Rural Rehabilitation Division of the F.E.R.A. to include drought relief cases within the scope of its activities. With the arrival of June, r935, the number of rural rehabilitation cases had swelled to $203,6 \mathrm{r} 2$, to say nothing of the hundreds of thousands of other rural families receiving either outright grants or work relief.

On the basis of the foregoing analysis, it is readily apparent that the fundamental purpose of the rehabilitation program was twofold; namely, first, emergency relief to a selective group of farm operators, and, secondly, rehabilitation through longrange corrective measures by means of constructive individual farming programs for the clients concerned. But to other agencies of the Resettlement Administration were left the broad aspects of the problem of long-range adjustments through the instrumentality of resettlement and land use planning. In regard to the first aspect of the rural rehabilitation program, according to the original intent of administrative officials when the Rehabilitation Division was set up, it was undoubtedly contemplated that the program emphasize long-range corrective measures through planned farm programs for rehabilitation clients. The chief purpose of the Division as originally declared was to "assist destitute farm families and other families residing in rural areas to become self-supporting and independent of emergency relief aid." This evidently meant more than a mere reclassification of the grants which such clients were to receive. But in so far as the program consisted of "furnishing" tenants and croppers (a service which landlords used to render but now could not, or would not if the government would do it) and of providing aid to drought families for the purchase of feed for livestock, the Administration was merely functioning as an emergency agency.

s If a farm operator was receiving both relief grants and rehabilitation advances, he was regarded as a rehabilitation client. 
During any given month only a small portion of the total rehabilitation cases may have received advances during that month, since advances of funds during previous months to an individual made of him a rehabilitation client until the loan was paid provided he was still a participant in the farm rehabilitation program. Accordingly, in December, x935, advances were made to 156,000 individual clients, 2600 of which were loan cases and 130,000 grant cases. ${ }^{4}$ This particular month, however, was an unusual one in this respect. For the most part, during the entire program, advances to rehabilitation clients were for the purchase of capital goods rather than for subsistence goods in the ratio of about three to one, varying of course from time to time and place to place.

In so far as the objective of the rehabilitation program was to raise the tenure status and economic position of submerged farm operators and farm laborers by means of long-range individual farm programs, it no doubt did not achieve its goal. Relatively few farm laborers and share croppers were made tenants, and in instances where such was the case, there is little evidence that the conditions and circumstances under which they were to operate could provide more than an element of security at a very low level of living. For the most part, they were merely removed from dependence upon certain types of work relief. Even then, much relief had to be provided for many rehabilitation clients because their small-scale farms offered no assurance of an independent existence. It is true, each rehabilitation client was supposed to have prepared for him by his immediate rehabilitation supervisor comprehensive farm plans that would eventually leave him actually rehabilitated-a moderately prosperous, self-respecting farm operator. This result, however, has not been achieved, and primarily for the reason that such farm plans as were made for clients were carelessly and hastily drawn up with one chief end in view, namely, that of getting subsistence from the soil in lieu of emergency grants and work relief. The program was largely in effect only work relief in tilling small individual plots of poor soil with teams and tools of poor quality, most of which were purchased with F.E.R.A. funds at highly inflated prices. In the main, the client was restored to an economic and tenure status of a character which had been largely responsible for sending hundreds of thousands to the relief rolls. His position achieved security so long as federal funds were forthcoming, but it was not one which by any means would establish him as an independent producer eventually able to weather the tide of another depression without public aid. More constructive land use adjustments and farm programs altogether unlike those, which had contributed to the agricultural distress were universally regarded by land use experts as indispensable. The Land Policy Section of the National Resources Committee, the Land Use Planning Section of the Division of Land Utilization of the United States Department of Agriculture, and various other federal and state agencies had made a start in tackling the chronic maladjustments contributing to agricultural distress from a long-range

'Farmers on Relief and Rehabilitation, W. P. A., Div. of Social Science Research (1936) p. 22. 
point of view. It was, however, at about this point in the development of the emergency and long-range aspects of the entire rehabilitation and readjustment program that the Resettlement Administration took over the entire job.

\section{The Resetrtement Administratton's Inherttance and Subsequent Program}

On July $\mathrm{r}$, 1935, the Resettlement Administration took over the administration of the rehabilitation and resettlement programs initiated by F.E.R.A., and also the major portion of the work started by the Land Policy Section of the National Resources Committee, and of the Land Use Planning Section of the United States Department of Agriculture. The chief objective in this change in administrative setup was to coordinate under one agency both the corrective measures of an emergency character and those aimed at evils of a long-run character which had contributed largely to growing agricultural distress for a number of years prior to the depression.

Thus, with this twofold objective in mind, the major portion of its program logically fell along two chief lines of action: first, the continuation of the rehabilitation program of the Rural Rehabilitation Division of F.E.R.A., and, second, the making of land use adjustments as a long-time program to prevent the continuation and/or recurrence of the situation with which the Rehabilitation Division was then trying to cope. The former line of action was carried on much as it had been done by the State Rehabilitation Corporations, except perhaps with less dispatch-because of the hierarchy of organization-and in that the policy of leasing land (at exorbitant or other prices) for occupancy by rehabilitation clients was largely discontinuedone policy much to its credit. The type of assistance which was afforded farm operators was, in the main, in the form of cash advances for (I) subsistence and (2) capital goods ${ }^{5}$ to be used upon the land on which they were then located or possibly might subsequently live upon. This aspect of rehabilitation was termed rehabilitation "in place" in contrast to the "resettlement" of families from poor land areas in areas of better land if rehabilitation under the latter circumstances seemed more feasible. Of course the "resettlement" of families under more favorable circumstances in new land areas was essentially a long-range program which could be effected only through a thorough study of the problem of desirable land use adjustments. In this connection, theoretically at least, much emphasis was to be placed upon the advice and counsel of land use planning specialists. This portion of the program was more difficult and, therefore, received relatively less attention. Yet, while this aspect of the program was the one in which much lasting good could have been achieved, because of lack of coordination in planning and because of divided responsibility in the details of procedure the results fell far short of the possible maximum in view of the personnel and funds available for instituting a

\footnotetext{
$\checkmark$ "Subsistence" goods referred chiefly to those necessary for current keep of the family and of work stock. "Capital" goods included durable goods used in the production of a crop.
} 
constructive program-an aspect which will be analyzed more at length in the succeeding section.

The strictly rehabilitation "in place" aspect of the program tapered off largely into one of advancing loans to needy owners, tenants, share croppers, and a few former agricultural laborers, to all of whom the usual avenues to credit were then closed, especially the resources of the Farm Credit Administration. Rehabilitation "in place" was, therefore, more nearly just another venture of the federal government in the extension of credit to high-credit-risk farmers than it was anything else. While associated with the Resettlement Administration, the writer received on his desk many letters forwarded from offices of the Farm Credit Administration which it had previously received from farmers pleading for credit based upon some shady security which was deemed an unjustified risk by the latter agency. This class made up the recruits to rehabilitation. In fact, any potential client who could secure credit from any other source was unacceptable to the Rural Rehabilitation Division.

There is no intent at this point, in the least, to disparage the liberal extension of credit to distressed farmers who cannot offer the security demanded by so-called sound banking practice-not that at all. The point simply is that such a policy partakes more of the character of an emergency measure than of a long-range, constructive readjustment-unless there is some fundamental basis for the contention that the chief factor contributing to agricultural distress has been the deficiency of farm credit. On the contrary, in all the literature on the subject of the factors contributing to the gradual decline of agricultural prosperity, we seldom, if ever, see the declining availability of credit listed as a factor. In fact, during the past few decades when the level of agricultural welfare has shown signs of sinking most rapidly, there has been a gradual extension of credit available to the farmer on more favorable terms than ever. The federal government through the Farm Credit Administration has contributed more than its share to this development. Under present day conditions a farmer's lack of security and the unavailability of credit to him are usually results of his distress and not its causes. The influence of institutional arrangements conducive to the poverty of certain classes can hardly be overcome by the creation of debts.

Quite true, to a certain degree, the availability of credit is a factor in the success or failure of an individual farmer, but the presence of credit alone is no assurance of success-the thing in itself has no particular value. It is the efficient-production functioning of credit which renders it a real asset in individual farming operations. Intelligently granted credit should constitute the means by which the individual farmer commands land and instrumental wealth commensurate with his ability to set up an efficient, economic farming unit. Furthermore, such credit wisely placed should result in a value ratio of output to input which exceeds I, else there can be no net value return for his operations. The first essential, therefore, in an analysis of the value of his operations is to regard credit as means and not as end. 
Accordingly, this point of view leads to several corollaries of the original proposition, namely, (I) the credit must not be used to purchase over-valued instruments in the form of land, teams, or tools; (2) it must be adequate to equip an economic farm production unit; (3) the expenditure of credit must be apportioned among land and other capital goods according to the system, or systems, of farming best adapted to the area. Practically every one of these fundamental principles was widely and consistently violated throughout the program, especially where rehabilitation was instituted as if it were a program solely to get rural people off direct and work relief by placing them back on the soil primarily to raise their own food.

Apropos the first principle mentioned above, the reader should recall that many rehabilitation clients, especially those who by usual occupation were share croppers or farm laborers, for the most part had neither land nor teams and tools to farm on their own account. These had to be provided by the Rehabilitation Corporation operating in a particular state. ${ }^{6}$ Good land in most instances was not available from landlords for occupancy-and especially perhaps for only temporary occupancyby tenants of the type that for the most part were being rehabilitated. Consequently much poor land was purchased or leased at prices which under normal circumstances would have secured lands of the best quality. Such lands were subdivided into small tracts, often not more than five or ten acres, and to most of them old shacks had to be moved or in other cases hovels existing thereon had to be renovated. The construction of fences, barns, and sheds, and the digging of wells presented other problems. It was in the administration of this part of the program that its weakest links were to be found.

Had it been a matter of paying the cash rent, or lease money, for land upon which an existing tenant was residing, and of advancing money for teams and tools which he had already committed himself to pay for, the task would have been greatly simplified. However, no such easy situation existed. In the first place, land had to be bought or leased. The latter course usually was followed. In lieu of direct payment of rent to the landlord, the Rehabilitation Division (then within the F.E.R.A.) was to apply the lease money to the erection of improvements upon the land in an amount not to exceed the value of the lease for a period ranging from one to five years. This amount became the obligation of the client who was to be rehabilitated thereon. The rehabilitation applied chiefly to the property, of the landowner, but since he could not feel assured of the usefulness of such a small tract of land thus improved after the expiration of the lease period, and was skeptical at times of the character of the man placed thereon, he wanted for the use of the land a sum commensurate with its average productivity plus liberal compensation for the risks involved. Necessarily the client, then, was obligated to pay for the use of his land a sum more than its productivity -at times, for only a three or five year's lease, a sum which would have been sufficient to give him title to the land in fee simple.

'Authorization had been granted to both the Resettlement Administration and Rehabilitation Corporations to expend money for the purchase or lease of land as well as to buy livestock and equipment. 
He had little choice in the matter, since arrangements for the land were made by his immediate rehabilitation supervisor. He could accept the terms or go unrehabilitated.

But this was only the alpha of his difficulties. Neither he nor his immediate rehabilitation supervisor could assume the responsibility of erecting or remodeling the house, constructing the outbuildings, or digging the well, etc. The development work was turned over to the Work Division of the F.E.R.A., which for the most part utilized relief labor in making the designated improvements. The assumption was, of course, that the contemplated improvements could be completed within the allowance made for the lease or rental of the land. It usually turned out like the farmer's bread and molasses-they would not come out even, and the improvements often were only partially completed. When the money allotment for such work was exhausted, there were no additional funds available for the completion of the job. The landowner would not do it for the benefit of the client or the government; the tenant would not do it if the improvements were immediately to become the property of the landowner; the government could not add more to the bill in payment for land which the client had not gotten.

Nevertheless, when this stage of development was reached, it was perhaps already March, or April, perhaps even well up in May. The time was long past for the client to move into his new rehabilitation location. Not even the earlier preparations for a crop, those ordinarily made by January $I$, such as plowing the land, had been started. Despite these handicaps, when he moved in, he probably found a shack with no floor, or if a floor, only a partially completed roof. Possibly the shanty had been completed, but he found no shed for his chickens, no barn for feed, or even a pen in which he could keep his mule (also sadly in need of rehabilitation) to prevent his straying over the crops that possibly would be growing later. If he had proceeded to the back yard, he would have found perhaps a well dug almost to water, but not quite. Yet the Work Division, having already exhausted the funds allotted for development, had moved elsewhere to repeat its haphazard performance. Possibly for the duration of his stay on the place the client would have to haul his water on a sled from some well or spring a mile or two away.

An incident, which is rather amusing-but not to the party involved-was the experience of a client on such a partially improved location is East Texas. He had a mule with eyes none too good, but the mule had neither pen nor pasture. The farmer also had a well, but the well had no water, nor did it have a cover over it. The mule, while slumbering one night, walked in his sleep. Fate determined that he should fall in the well, but the well was not a very deep one. The client had neither the means to remove the unhappy mule, nor the authority to hire anyone at government expense with equipment to get him out. He could only notify the rural supervisor, who, upon consulting his rehabilitation Hoyle, found that the use of government funds was permitted only for the purchase of subsistence or capital 
goods. Nothing could be found pertaining to expenditures involved in getting a client's mule out of a well. The State Office was immediately notified, but matters involving deviations from the letter of the law had to clear through the Regional Office in Oklahoma, which also had to consult Washington on similar matters. The last report was that the mule was patiently waiting while officials conferred on rules of procedure. This incident, of course, is a rare case, but occasions were numerous in which the procedure bogged down in red tape and rigid rules of order. Those in the field charged with getting the job done had a superabundance of responsibility but very little authority. On the whole, the motives were worthy, but the means to the ends were circuitous and expensive. All the while the advances of funds, even for unfinished work, were charged to the account of the client.

The program would not have looked so gloomy had a client worthy of the effort been giving a farming unit somewhere near the economic family-sized unit prevailing in his area. On the contrary the client was set up under conditions not greatly different from those which were generally accepted as contributing factors to his inability to weather the storm of the depression. It can be called "rehabilitation" in the sense that the clients were provided for so long as federal funds were forthcoming, or in that they were not still on work relief. But the program is hardly "rehabilitation" from the standpoint of a corrective program that looks toward permanent readjustment with the view to achieving higher standards of living with a modicum of security from a repetition of their existing distress.

By way of summary, rehabilitation clients, in the main, were located under the following conditions:

(r) On relatively small farms, a factor which is a large contributor to existing maladjustment.

(2) The land was usually relatively poor, nationally recognized as a depressing factor.

(3) Both land and equipment were frequently purchased at inflated prices.

(4) Farm plans provided chiefly for the growing of subsistence goods only, which at best should constitute only about $35 \%$ of the normal farm family budget.

(5) The small-scale setup frequently contemplated only part-time farming, i.e., that a client would find employment outside of farming to supplement his deficient farm income. Part-time farming is worthy of consideration in most farming areas of the United States only if the part-time farmer's outside employment is sufficiently remunerative to allow him to forget his farming. When times are good, he probably can do this; when depressions hit, he has no job, and his small subsistence patch becomes only a squatter's plot, and the part-time farmer becomes a relief client.

(6) Practically all clients were located only on arable land while the aptitudes and experiences of some better qualified them for gaining a livelihood in the production of livestock.

(7) The particular systems of farming best adapted to the locality in which the client was located had little influence upon the size of his unit or the nature of the program outlined for him.

(8) The depths to which one had sunk, and the character of his needs were relatively small factors in determining whether he was chosen for rehabilitation. Generally the 
lower his position the less likelihood he had of becoming a client. Relatively more owners and tenants than share croppers and laborers were selected for rehabilitation. In proportion to their numbers, only half as many negroes were selected for rehabilitation as were whites, and when selected, advances received by them were hardly half those received by white clients in similar stations.

(9) The amount and quality of the teams and tools assigned a client were hardly commensurate with the amount of land allotted him, thus sacrificing the efficiency of an optimum relation between the man, land, and equipment factors of production.

The plight of the rehabilitation client can be inferred from the table below of the sizes of farms operated by relief and rehabilitation clients, and of those operated by all farmers (even including those on relief) during the year 1935 .

Comparative Size of Farms Operated by All Farmers, by Areas, and Types of Tenure, and Those Operated by Relief and Rehabilitation Clients ${ }^{\top}$

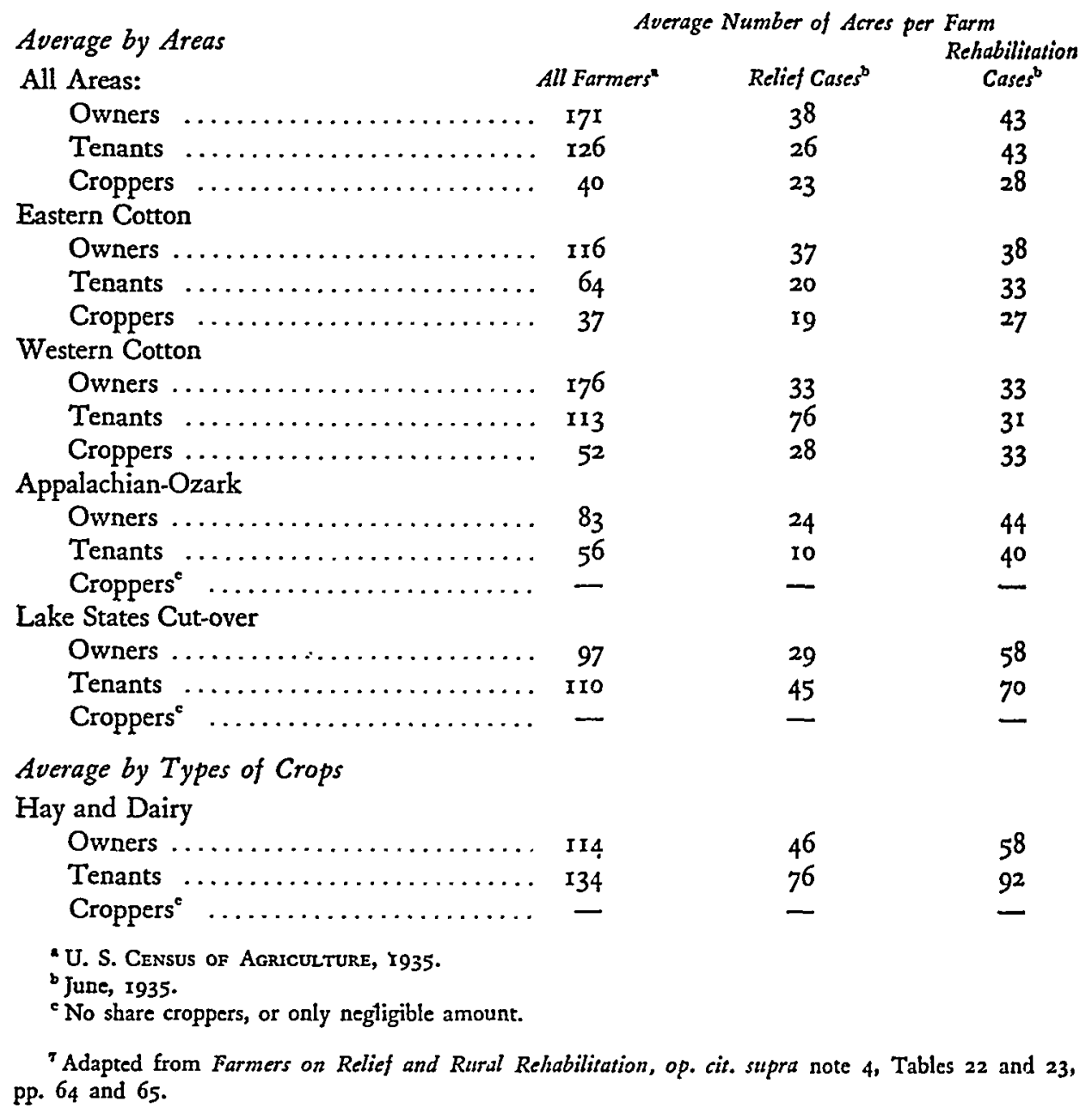


Corn Belt

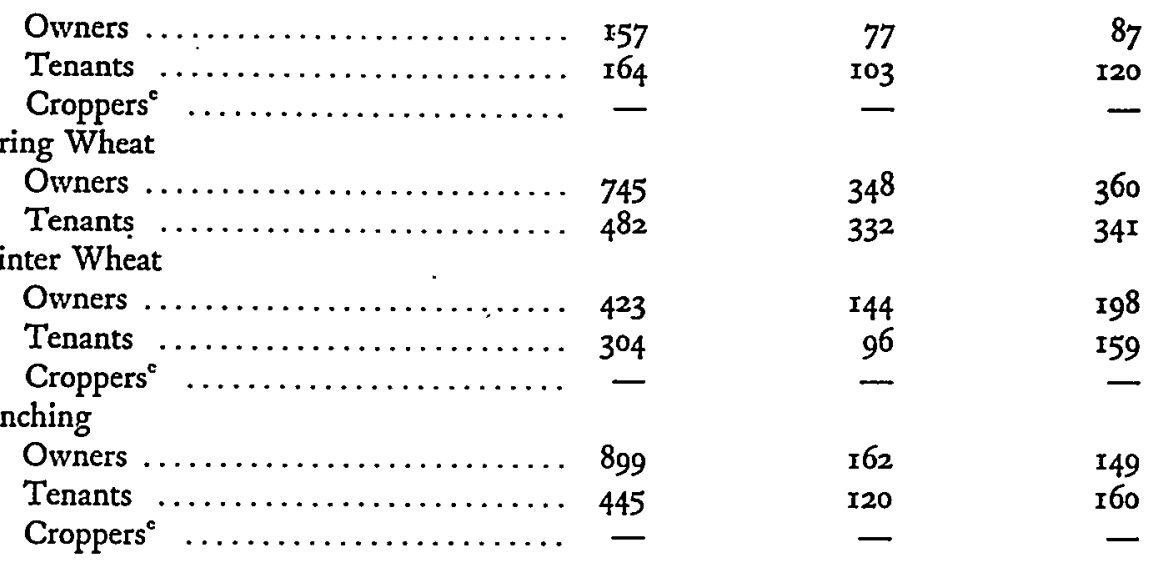

An analysis of the data above reveals a most striking contrast in the size of farms operated by farmers on relief and rural rehabilitation within given areas. They point also rather conclusively to the chief determining factor in the causes of the distress, as well as to the road to reconstruction. An interesting side-light here is the observation that distressed so-called "owners" usually operated smaller farms than did tenants in the immediate vicinity. This is conclusive evidence, it seems, that ownership without respect to equity and to the adequacy of the farm unit may represent a process of "freezing" on the agricultural ladder rather than of ascending it. We too frequently talk loosely of climbing an "agricultural ladder" that is lying flat on the ground. Despite the implications involved, many Resettlement Administration officials have fostered the participation of tenants in what must remain a form of useless exercise, unless, and until, there is an intelligent attack on the institutional factors conducive to poverty and, therefore, tenancy. For example, in the Lake States Cut-over Area, $78 \%$ of the rural relief cases represented owneroperators who could exist only at a relatively poor level even in normal times. Ownership of uneconomic farm units on poor land is no indication of any successful climb up the agricultural ladder. For the most part "ownership" is only a legal concept which has had assigned to it any number of economic implications which essentially it does not possess.

Also, with respect to the amount and value of livestock and equipment possessed by the distressed owners on small-scale farms, the owner-operators were at a disadvantage in comparison with the better grade tenants who had put the whole of their limited capital into teams, tools, and equipment rather than a portion of it into poor land, resulting in a deficiency of each factor of production. Likewise, tenants on relief were deficient in the ownership of these means of production as compared to those owned by their associates off relief and rehabilitation. All these major factors of production represent wealth, which represents earning capacity by some one somewhere along the line. What American farmers in chronic distress need, therefore, is more earning, or income-yielding, capacity. For the most part this end 
can be achieved more effectively through long-time planning than through shorttime lending.

Even though rehabilitation as has been carried on has its merits as an emergency measure, the exigencies of the situation in such a time preclude the possibility of the adoption of the most effective measures for long-run results. The rational thing to do is to avert the possibility of distress by making adjustments during normal times in land use, the distribution of the rural population, and in existing systems of farming. It was the early recognition of this fact which accounted for the establishment in the Resettlement Administration of the Division of Land Utilization, and, within this division, of the Land Use Planning Section. But here again the machinery could not "click" properly, largely because of the division of responsibility in numerous matters of procedure.

\section{Some Unplanned Planning}

The recognition of the need for planning is one thing; to get plans made for executing planning is quite another thing. To be agreed upon the objectives is not so difficult, but the matter of what agencies, or sub-divisions, of a large organization like the Resettlement Administration were to determine the means to achieve the desired ends brought many delays and numerous blue-prints of plans back from Washington to be done all over again. Often before the required revisions could be made, some axe wielder in a particular section had changed his mind, or emergency funds had been reshuffled, and the revisions also had been for naught.

The king pin in the set-up logically was planned land use. But the execution of this program involved an almost inestimable number of laborious processes, chief among which were the following:

(I) An inventory and classification of the land supply of the nation.

(2) An analysis of the nature and location of maladjustments in land use.

(3) An analysis of the nature, extent, and location of necessary readjustments to be made.

(4) The determination of the extent and location of sub-marginal land areas used for cropping which logically should be retired from such use and more appropriate uses found.

(5) The determination of the number and the location of families that might be involved in plans for relocating them on better land.

(6) The selection of suitable resettlement areas, and the planning, construction and development of resettlement projects.

(7) The optioning, appraisal, and purchase of lands for resettlement, retirement, or reforestation as the particular situation may warrant.

(8) The legal work connected with the examination of abstracts, deeds, etc.

(9) Processes incident to making payment for lands leased or purchased.

(ro) Architectural work in connection with the planning of farm houses, the erection of community social centers, cooperative canning plants, etc.

(II) Engineering work in connection with the construction of buildings, roads, drainage systems, etc.

(12) Business management functions incident to the stocking of supplies, the issuance of travel orders, handling the mailing and filing system, etc. 
(r3) Accounting work in connection with keeping records of money spent and still, available, issuing salary checks, etc.

The list could continue almost without end. All in all, there was an effort to group these various tasks into several divisions, each of which was divided into sections and these into units and sub-units. However, since the chief objective was planning, there should have been a classification of the various divisions into (I) policy-determining divisions, and (2) service divisions. The function of the latter would have been to serve more or less as auxiliary units in the execution of plans. There was much talk of policy-determining functions, and policy-executing functions, but nobody could feel sure who had what. The intricacies were legion, but a specific case will suffice to illustrate the major aspect of the problem.

For instance, the work of the Land Use Planning Section was to be basic to the entire program. It classified the land, designated the sub-marginal land areas for retirement and the areas for resettlement. It had the responsibility for designating the areas where the farms were too small, where the farming population was pressing upon rural opportunities, and the areas where certain systems of farming had the greatest likelihood of succeeding. If only it had had the authority to follow through the various steps in the process of readjustment, there probably would have been much less done for which it was generally felt that someone owed an apology.

When the Land Use Planning Section designated an area as suitable for resettlement, this was done because of evidence that it was a "good" land area. But good land is only a relative rather than an absolute concept. It is good only in relation to a certain price limit, in relation to certain types of crops, farming systems, and especially only in relation to the size of farm unit set up for which the area is best adapted. A most important factor also is whether it is good enough for one thousand dollars' worth of land to support an additional investment overhead (largely nonproductive) of some five or six thousand dollars. Even a good resettlement area is not fool-proof against every conceivable sort of farm management blunder, procedure to the contrary notwithstanding.

Once the selection of the area was made, it then fell into the hands of one or more development units. An engineer could (and did in many instances) plan to run roads through the middle of the best crop land section, he could locate farm residences a half mile from the pasture land, or cut the whole resettlement area, gridiron fashion, into sixty-acre blocks without regard to the amount and quality of the land which fell into each tract. Those responsible for the planning and erection of farm houses could plan \$5,000 homes with hand-finished floors and shellacked knotholes on a tract of land that would stagger under the weight of a $\$ 2,000$ structure. The selection of the area might be made on the assumption that not less than eighty acres could possibly constitute an economic family unit, and some one would come down from Washington with ready-made plans for units consisting of only 24 acres. This identical thing happened in connection with program planning in the old 
Southeast after the Land Use Planning Section recommended not less than eighty"acre tracts, and felt a bit apologetic for doing that.

Furthermore the Rural Rehabilitation Division was permitted to carry on its most intensive program of rehabilitation in areas which the Land Use Planning Section had already designated as definite "Problem Areas," and where the continuation of farming operations should have been discouraged. The production of crops was recommended for many farmers whose aptitudes would have assured greater success on larger units utilized for combination livestock-crop farming. Within a given resettlement project farms were almost without exception of uniform size, ignoring the differences in individual managerial capacities and the size of families. A farmer in a designated sub-marginal land purchase area could option his land to the government, and wait possibly a year and a half before the Legal Division could pass on the abstract of title so he could obtain his pay. In the meantime, land values might be rising and farms once available already taken up. $\mathrm{He}$ was a big loser for his reluctant cooperation, and maladjustments were being incubated almost as fast as readjustments were consummated.

Of recent date, however, developments point upward. An old, established agency, the United States Department of Agriculture, has inherited the task of carrying on. It has a large corps of well-trained technicians. The emergency period of the program has apparently passed. Another encouraging sign is the fact that steps already have been taken in Washington to coordinate activities in all phases of land utilization work. If this objective can be achieved, and authority can accompany responsibility, lasting adjustments may yet be wrought. At any rate, the critical nature of the problem warrants the best job that human ingenuity can give to it. It will be better that it be poorly done than not tackled at all. 